\title{
Development and validation of HPLC method for the quantification of clotrimazole in a gelatin film formulation
}

\author{
Surekha Kalshetti ${ }^{{ }^{*}}$ (D) and K. P. Rao ${ }^{2}$
}

\begin{abstract}
Background: Clotrimazole is used to treat topical vaginal yeast infections. Vaginal gelatin film formulations of clotrimazole were prepared, and the present study aims to develop an HPLC method for quantifying clotrimazole in the film formulation.

Results: The chromatographic separation of components was achieved on a Phenomenex Luna C18(2) (150 × 4.6 $\mathrm{mm}, 5 \mu \mathrm{m})$ stationary phase with Phenomenex Security Guard Cartridge C18 $(4 \times 3 \mathrm{~mm})$ using acetonitrile and water $(70: 30 \% \mathrm{v} / \mathrm{v})$ as mobile phase. The flow rate was $1.0 \mathrm{ml} / \mathrm{min}$ and the absorbance was monitored at $210 \mathrm{~nm}$. Clotrimazole was eluted at $5.6 \mathrm{~min}$. The procedures and capabilities of the method were evaluated against the criteria for system suitability, specificity, linearity, precision, accuracy, and robustness as defined by the ICH guidelines. The method showed good linearity $\left(R^{2}=0.999\right)$ in the range of $10-50 \mu \mathrm{g} / \mathrm{ml}$ and an average recovery of $101.05 \%$.
\end{abstract}

Conclusion: The method could be applied for the quantification of clotrimazole in the gelatin film formulation.

Keywords: RP-HPLC, Clotrimazole, Gelatin film

\section{Background}

Clotrimazole, an imidazole derivative (Fig. 1), is a broadspectrum antifungal. It inhibits the biosynthesis of ergosterol, a component of the fungal cell membrane, and this affects the permeability of the cell membrane, which results in leakage and loss of essential intracellular compounds and finally causes cell lysis [1].

Clotrimazole is used to treat vaginal and skin yeast or fungal infections, rashes, oral thrush, athlete's foot, jock itch, ringworm, etc. This is administered orally or applied topically. It is commonly available in various dosage forms, such as a cream, vaginal tablet, or throat lozenge. Topically, clotrimazole is used for vulvovaginal candidiasis. Tablets and creams are inserted into the vagina. Clotrimazole gelatin films have been developed for vaginal application in our laboratory.

\footnotetext{
* Correspondence: smkalshetti10@gmail.com

'DSTS Mandal's College of Pharmacy, Solapur, India

Full list of author information is available at the end of the article
}

Few methods have been reported for the determination of clotrimazole individually or in combination in different formulations. These include HPLC [2-7], centrifugal partition chromatography [8], HPTLC [9], and spectrophotometry [10-12] for the quantification of clotrimazole. According to a survey of analytical literature, none of the reported methods describes a simple HPLC method for estimation of clotrimazole in gelatin film formulation. Furthermore, buffers were used in the mobile phase of reported HPLC methods. Thus, there was a need for a validated simple HPLC method to determine clotrimazole in gelatin film formulation without any pretreatment to sample.

\section{Methods}

Chemicals

Clotrimazole was obtained from Glenmark Laboratories Ltd, Mumbai, India. HPLC-grade acetonitrile LiChrosolv, water LiChrosolv, and methanol were procured

\section{Springer Open}

(๑) The Author(s). 2021 Open Access This article is licensed under a Creative Commons Attribution 4.0 International License, which permits use, sharing, adaptation, distribution and reproduction in any medium or format, as long as you give appropriate credit to the original author(s) and the source, provide a link to the Creative Commons licence, and indicate if changes were made. The images or other third party material in this article are included in the article's Creative Commons licence, unless indicated otherwise in a credit line to the material. If material is not included in the article's Creative Commons licence and your intended use is not permitted by statutory regulation or exceeds the permitted use, you will need to obtain permission directly from the copyright holder. To view a copy of this licence, visit http://creativecommons.org/licenses/by/4.0/. 
from Merk Pvt. Ltd., Mumbai. Gelatin and sodium lauryl sulfate were procured from S D Fine-Chem Ltd, Mumbai. Gelatin films (3\% w/w of clotrimazole) were prepared in the laboratory.

\section{Instruments}

The Younglin Acme 9000 HPLC system consisting of the components, 4 Channel Vacuum Degasser and Mixer SDV50A, Gradient Pump SP930D, Rheodyne Injector, Phenomenex Luna C18(2) $(150 \times 4.6 \mathrm{~mm}$, $5 \mu \mathrm{m})$ column with Phenomenex security guard cartridge C18 $(4 \times 3 \mathrm{~mm})$, and UV-VIS Detector UV730D, was used. The equipment was controlled by PC installed with the Younglin Autochro 3000 Chromatograph data system software. Shimadzu UVVis Spectrophotometer 1800, Shimadzu Electronic balance AY220, Borosil All Glass Filter with Nylon 6,6 membrane $0.45 \mu \mathrm{m} 47 \mathrm{~mm}$ filters, and Phenomenex RC membrane $0.45 \mu \mathrm{m} 15 \mathrm{~mm}$ syringe filters were used.

\section{Preparation of standard solution}

Ten milligrams of clotrimazole was weighed and transferred into $10 \mathrm{ml}$ volumetric flask. $5 \mathrm{ml}$ of the methanol was added to clotrimazole and sonicated for $10 \mathrm{~min}$; the volume was made up to the mark with methanol (flask A). An aliquot of $5 \mathrm{ml}$ from flask A was transferred into $50 \mathrm{ml}$ volumetric flask, and the volume was made up of the mark with methanol (flask B) to obtain a solution of clotrimazole $(100 \mu \mathrm{g} /$ $\mathrm{ml})$.

\section{Preparation of sample solution}

Film equivalent to $10 \mathrm{mg}$ of clotrimazole $(332 \mathrm{mg}$ ) was taken in a $50 \mathrm{ml}$ volumetric flask and dissolved in $40 \mathrm{ml}$ of $1 \%$ sodium lauryl sulfate (SLS) solution with stirring at $50{ }^{\circ} \mathrm{C}$. The volume was made up to the mark with SLS solution (flask C). An aliquot of $1 \mathrm{ml}$ from flask C was transferred into a $10 \mathrm{ml}$ volumetric flask and a mobile phase was added up to the mark to obtain a sample solution (flask D).

\section{Selection of UV wavelength}

A solution of clotrimazole in the mobile phase $(10 \mu \mathrm{g} /$ $\mathrm{ml}$ ) was scanned in the range of $200-400 \mathrm{~nm}$ in a UVVIS spectrophotometer, and $\lambda_{\max }$ was selected from the UV spectrum.

\section{Method development and optimization}

To achieve satisfactory separation of clotrimazole, solvents of different proportions were tried as binary eluents on the $\mathrm{C} 18$ column. However, $\mathrm{ACN}$ achieve 
good satisfactory results. The optimized chromatogram and optimized conditions are decided on the basis of system suitability parameters.

\section{Chromatographic conditions}

The chromatographic separation of components was achieved on a Phenomenex Luna C18(2) $(150 \times 4.6 \mathrm{~mm}$, $5 \mu \mathrm{m})$ stationary phase with Phenomenex Security Guard Cartridge C18 $(4 \times 3 \mathrm{~mm})$ using acetonitrile and water (70:30\% v/v) as mobile phase. The flow rate was $1.0 \mathrm{ml} /$ min and the absorbance was monitored at $210 \mathrm{~nm}$. The volume of the sample was $20 \mu \mathrm{l}$.

\section{Method validation}

The method has been evaluated for system suitability, specificity, linearity, precision, accuracy, robustness, and stability of solution as per ICH guideline Q2(R1) [13].

\section{System suitability}

System suitability parameters (capacity factor, tailing factor, number of theoretical plates, and resolution of peak) were assessed by injecting a blank mobile phase followed by clotrimazole solution $(20 \mu \mathrm{g} / \mathrm{ml})$.

\section{Specificity}

The specificity of the method has been established by comparing the chromatograms obtained by injecting blank (mobile phase), solution of clotrimazole $(20 \mu \mathrm{g} /$ $\mathrm{ml}$ ), and sample solution of clotrimazole gelatin film. The effect of excipients used in film was checked. The parameters retention time, tailing factor, and resolution were calculated in order to prove that the method chosen was specific.

\section{Precision}

Precision was assessed by injecting six samples of clotrimazole solution $(20 \mu \mathrm{g} / \mathrm{ml})$ on the same day (repeatability) and a different day (intermediate precision). The precision of the method was investigated as \%RSD of the response.

\section{Linearity}

Ten, $20,30,40$, and $50 \mu \mathrm{g} / \mathrm{ml}$ of clotrimazole solutions were prepared by diluting the solution from flask B with mobile phase. Solutions were filtered through $0.45 \mu \mathrm{m}$ syringe filter and injected in an HPLC system to measure the peak area. The calibration curve (peak area v/s concentration) was plotted. The correlation coefficient of the calibration curve was determined to ensure the linearity of the analytical method.

\section{Accuracy}

Recovery studies were conducted by the standard addition (spiking) technique to the matrix of gelatin film.
In this method, 80,100 , and $120 \%$ of three different levels of pure drug $(1.6,2$, and $2.4 \mathrm{ml}$ from flask B) were added to the previously analyzed sample solution $(0.5 \mathrm{ml}$ from flask $\mathrm{C}$ ) in the $10 \mathrm{ml}$ volumetric flask and diluted to $10 \mathrm{ml}$ with mobile phase. Solutions were filtered through $0.45 \mu \mathrm{m}$ syringe filter and injected in an HPLC system to measure the peak area. Accuracy was evaluated as recovery values of the clotrimazole.

\section{Robustness}

Deliberate minute variations in the chromatographic conditions such as flow rate $( \pm 0.1 \mathrm{ml} / \mathrm{min})$, acetonitrile ratio in the mobile phase $( \pm 2 \%)$ have been made. After each change, assay results were checked by injecting the clotrimazole solution $(20 \mu \mathrm{g} / \mathrm{ml})$ into the chromatographic system and the results were compared with those under the original chromatographic conditions.

\section{Solution stability}

The stability of the clotrimazole solution $(20 \mu \mathrm{g} / \mathrm{ml})$ was assessed over $24 \mathrm{~h}$ at room temperature. The peak area and retention time were evaluated after injecting clotrimazole solution $(20 \mu \mathrm{g} / \mathrm{ml})$ into the system after every $8 \mathrm{~h}$.

\section{Analysis of clotrimazole film}

Sample solution (flask D) was filtered through $0.45 \mu \mathrm{m}$ syringe filter and injected in an HPLC system to measure the peak area.

\section{Results}

\section{Method development}

Two hundred ten nanometers was selected as the wavelength of determination from the UV spectrum of clotrimazole (Fig. 2).

Clotrimazole was eluted at $5.6 \mathrm{~min}$. Figure 3 illustrates a typical chromatogram obtained at optimum conditions.

\section{Method validation System suitability}

After setting the optimum conditions, system suitability parameters for the method are determined and compared with recommended limits. The clotrimazole was repeatedly eluted at $5.6 \mathrm{~min}$, tailing factor for peak less than 2 indicating good peak symmetry, and a number of theoretical plates always greater than 2000 ensure good column efficacy. Results are represented in Table 1.

\section{Specificity}

The clotrimazole was eluted at $5.6 \mathrm{~min}$ in both a chromatogram of standard clotrimazole (Fig. 3) and 


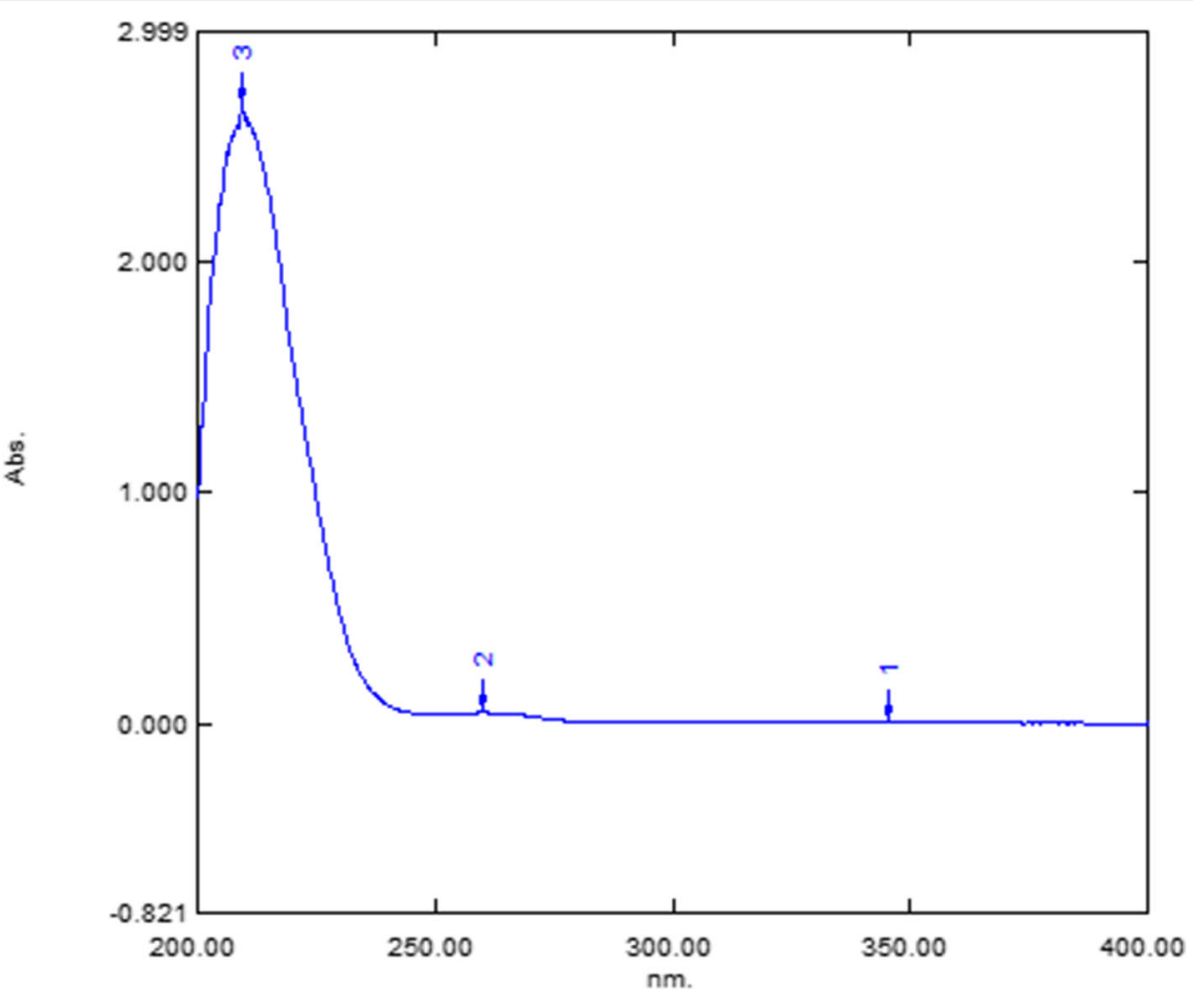

Fig. 2 UV spectrum of clotrimazole

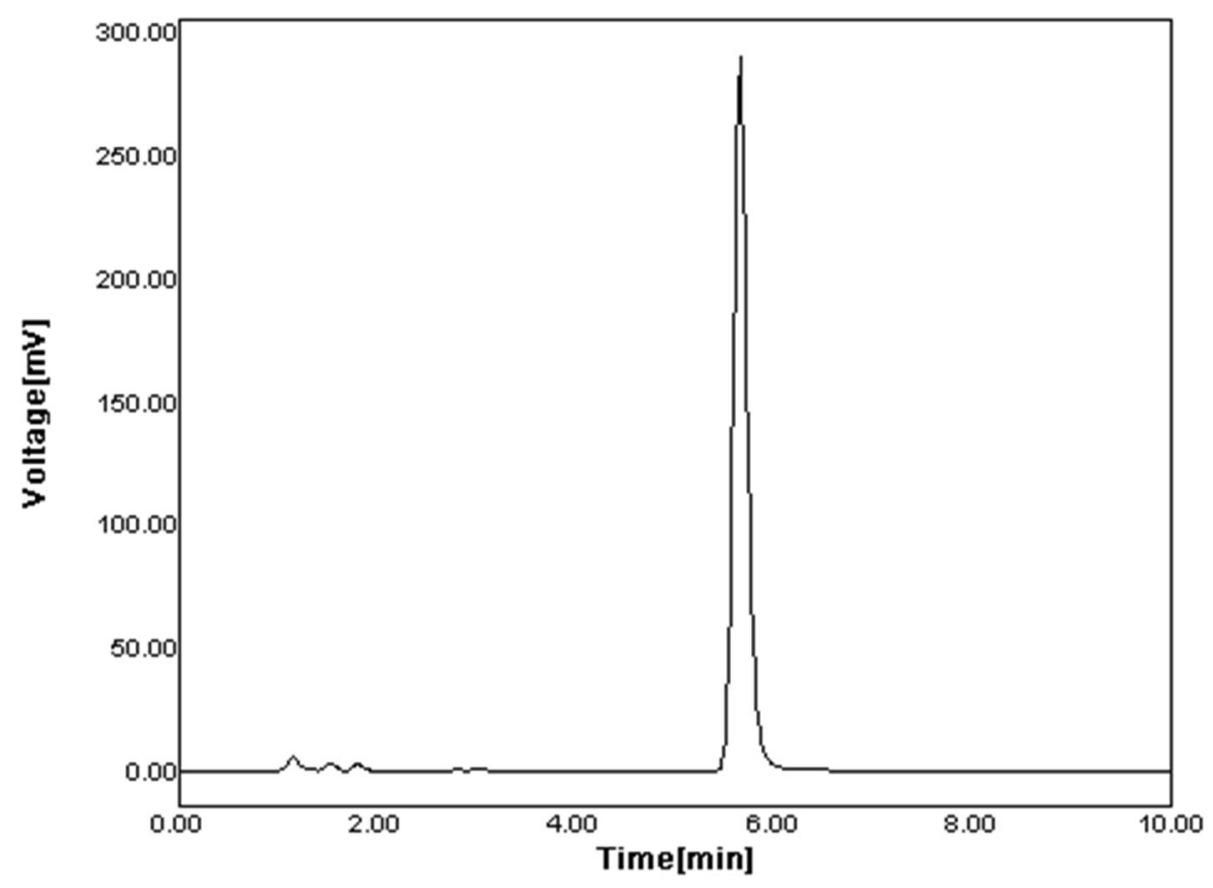

Fig. 3 Chromatogram of clotrimazole $(20 \mu \mathrm{g} / \mathrm{ml})$ 
Table 1 System suitability results

\begin{tabular}{lll}
\hline Parameter & Criteria & Clotrimazole \\
\hline Capacity factor $\left(\mathrm{k}^{\prime}\right)$ & $\mathrm{k}^{\prime}>2$ & 4.2 \\
Tailing factor $(\mathrm{T})$ & $\mathrm{T}<2$ & 1.1 \\
Theoretical plates $(\mathrm{N})$ & $\mathrm{N}>2000$ & 10,545 \\
Resolution factor $\left(\mathrm{R}_{\mathrm{s}}\right)$ & $\mathrm{R}_{\mathrm{s}}>2$ & 11 \\
\hline
\end{tabular}

clotrimazole gelatin film (Fig. 4). The clotrimazole peak in film is properly resolved from another excipient's peak and shows no interference from the excipients of the film (Fig. 5).

\section{Linearity and range}

The analytical calibration curve is linear in the range of $10-50 \mu \mathrm{g} / \mathrm{ml}$ and indicates the closeness of the correlation coefficient $\left(R^{2}\right)$ to $1(0.999)$. The linear regression equation is $\mathrm{y}=149.91 \mathrm{x}-36.7$. (Figs. 6 and 7, Table 2).

\section{Precision}

Repeatability and intermediate precision have been expressed by the relative standard deviation of peak area response (Table 3 ). The results ensure the high precision of the method where data was expressed in \%RSD (acceptance limit \%RSD $<2$ ).

\section{Accuracy}

Accuracy was assessed by spiking of a known quantity of clotrimazole to the film sample solution of 3 concentration levels (80,100, and 120\%) and expressed as percent recovery by the assay of a known added amount of clotrimazole in the film sample. Results for recoveries are shown in Table 4.

\section{Robustness}

No significant changes were noticed on $20 \mu \mathrm{g} / \mathrm{ml}$ of clotrimazole assay results upon applying small variations to the chromatographic conditions, flow rate, or mobile phase ratio. Results for robustness are presented in Table 5.

\section{Solution stability}

Clotrimazole solution was stable for $24 \mathrm{~h}$ at room temperature. The stability results have been assessed for the difference from zero-time injections, where no change in the peak areas was observed (Table 6).

\section{Analysis of clotrimazole gelatin film}

The developed and validated method was applied for the determination of clotrimazole in gelatin film. The result of the assay of the film is shown in Table 7. Gelatin film contains $2.94 \%$ of clotrimazole.

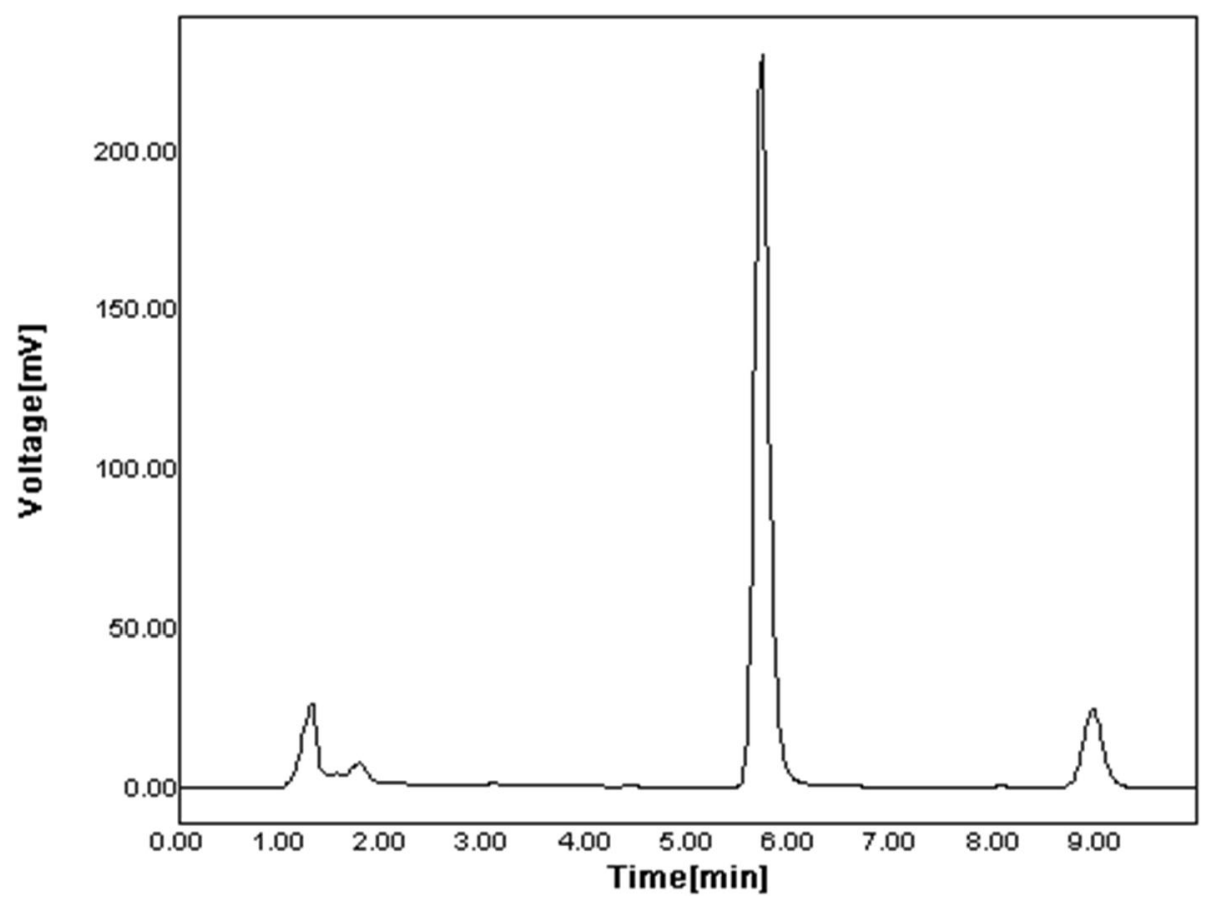

Fig. 4 Chromatogram of clotrimazole gelatin film 


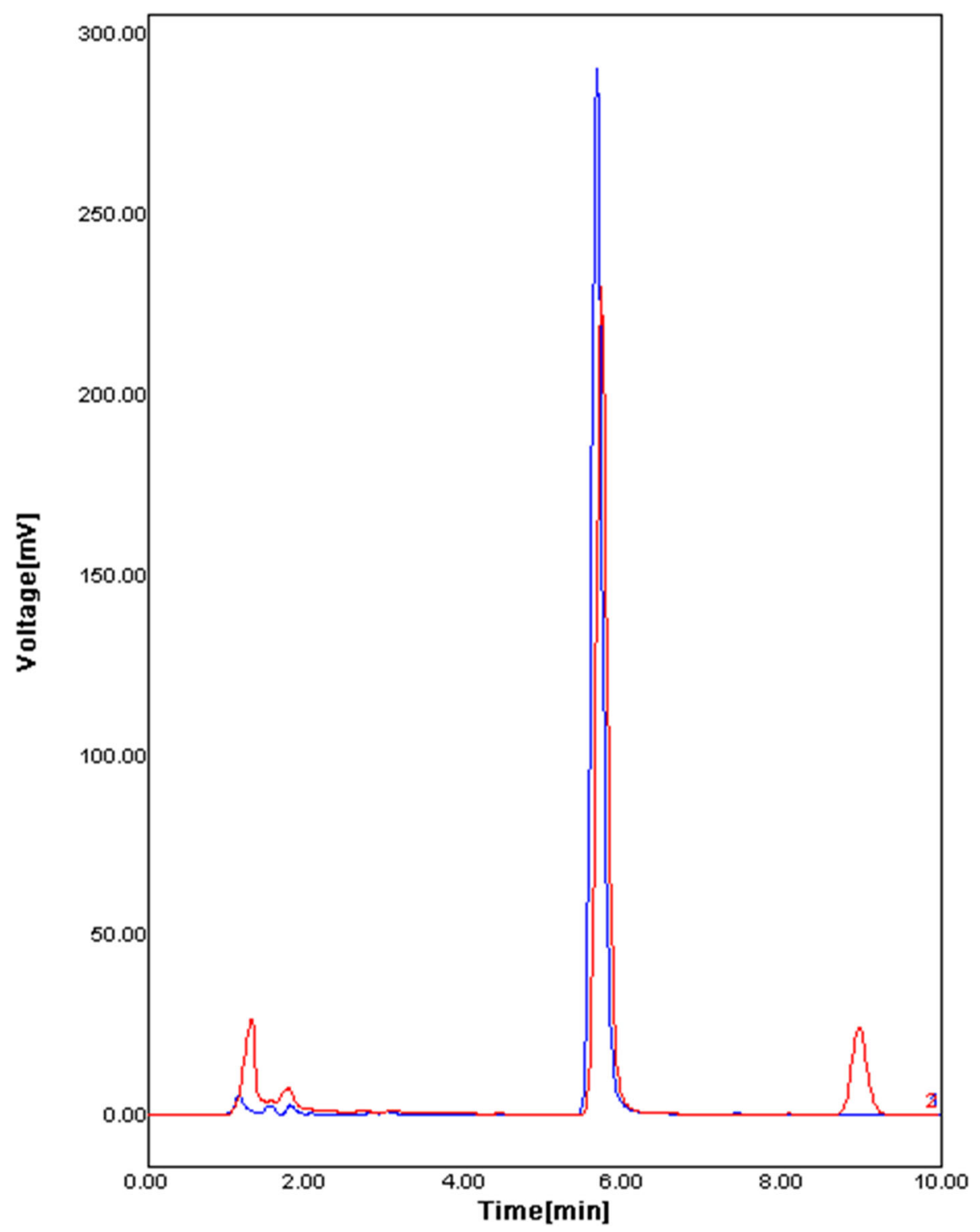

Fig. 5 Overlay of chromatograms of std clotrimazole (blue) and clotrimazole film (red)

\section{Discussion}

\section{Method development}

Optimization studies are carried out to develop the HPLC method for the determination of clotrimazole. In this case, the mobile phase parameter was investigated. The optimum parameters are selected based on the retention time and peak shape.

Two hundred ten nanometers is selected as the wavelength of determination because of the maximum absorption of the analyte. Also, the baseline obtained with this wavelength was horizontal. Similarly reported by Rajameena [4], clotrimazole was detected at $254 \mathrm{~nm}$ in some reported methods; however, we observed no UV absorption above $250 \mathrm{~nm}$ (Fig. 2).

Acetonitrile is commonly used as an organic solvent for the determination of clotrimazole in the reported methods. In addition to that, it has the ability to produce a better peak shape compared to methanol. Therefore, acetonitrile is selected as an organic solvent. Different isocratic profiles were explored by increasing the acetonitrile ratio to obtain a retention time less than $10 \mathrm{~min}$ as well as the peak symmetry. In this study, the acetonitrile ratio was increased, because it caused a shorter retention time. In addition, acetonitrile has higher 


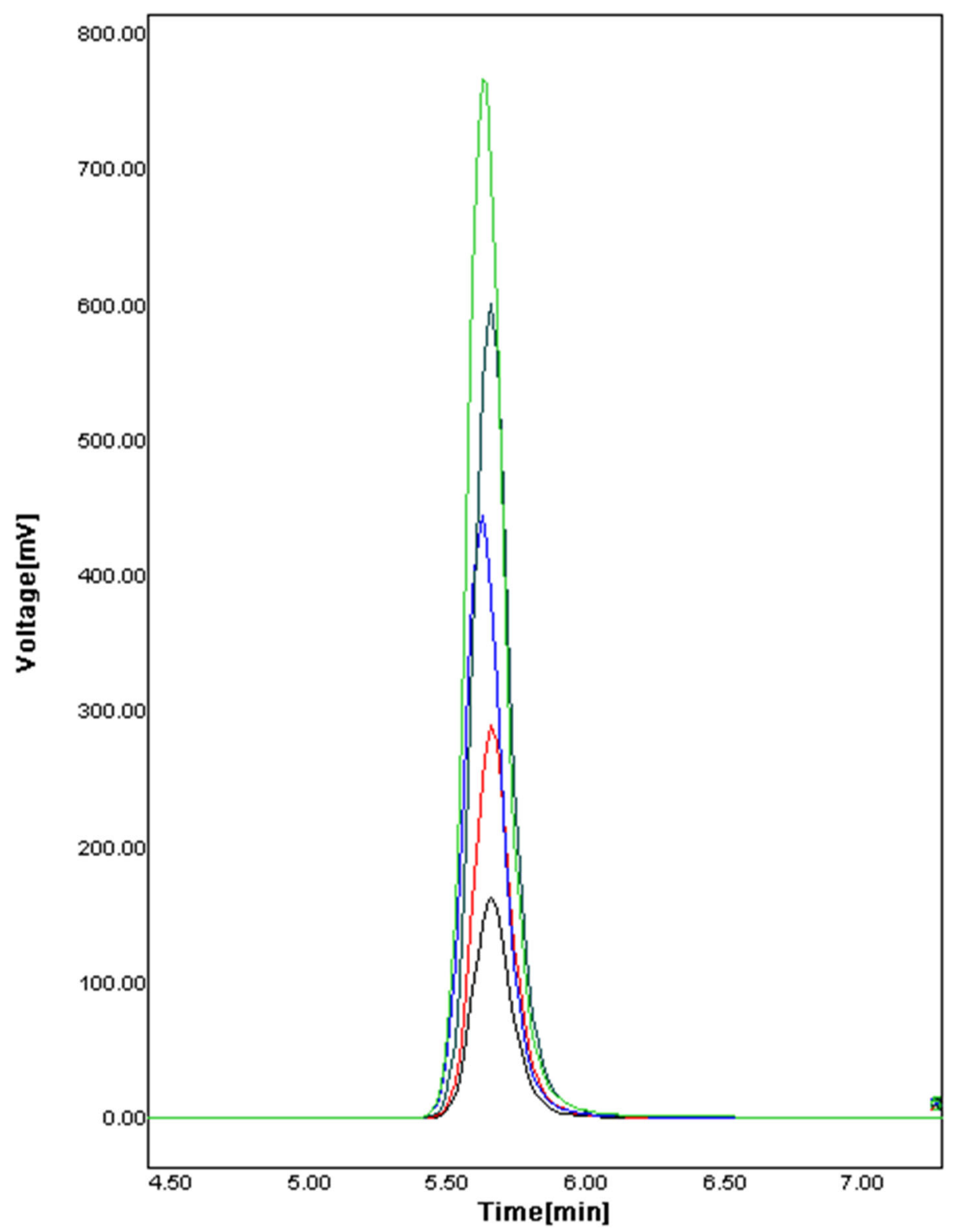

Fig. 6 Overlay of chromatograms of 10,20,30, 40, and $50 \mu \mathrm{g} / \mathrm{ml}$ of clotrimazole

elution strength, which improves the peak shapes. The flow rate of $1.0 \mathrm{ml} / \mathrm{min}$ is chosen as the flow rate of the method. The injection volume was $20 \mu \mathrm{l}$, and the experiment was carried out at $25{ }^{\circ} \mathrm{C}$. Clotrimazole was shown good retention on the $\mathrm{C} 18$ column. Early trials of higher organic proportion in the mobile phase retain clotrimazole on the C18 column.

\section{Method validation}

The system suitability parameters, capacity factor, tailing factor, theoretical plates, and resolution factor are within the recommended limits, so the method is suitable for the analysis.

Demonstration of the discrimination of the analyte in the presence of impurities and/or excipients is involved in the specificity. There is no interference from the excipients of the film to the clotrimazole peak. Hence, the method is specificity.

The method is linear $\left(R^{2}=0.999\right)$, precise $(\% \mathrm{RSD}<$ $2)$, accurate $(100-101.66 \%)$, and robust $(\%$ RSD $<2$ ). Analysis of clotrimazole gelatin film is done by this method. 


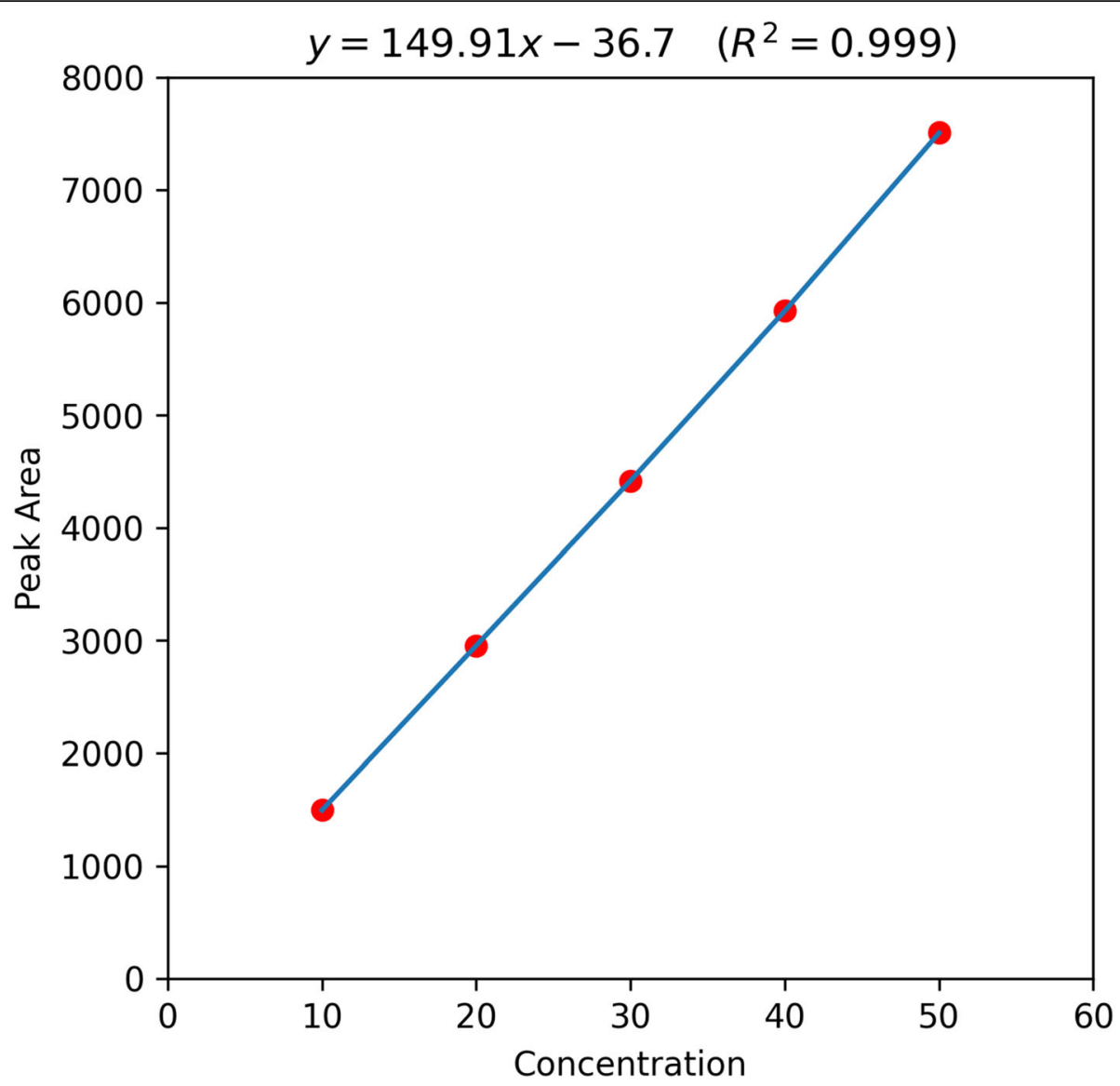

Fig. 7 Calibration curve of area vs concentration in $\mu \mathrm{g} / \mathrm{ml}$

Table 2 Linearity of response for clotrimazole

\begin{tabular}{ll}
\hline Concentration $(\boldsymbol{\mu g} / \mathbf{m l})$ & Peak area \\
\hline 10 & 1496 \\
20 & 2956 \\
30 & 4419 \\
40 & 5925 \\
50 & 7507 \\
\hline
\end{tabular}

Table 3 Precision result as the peak area of clotrimazole $(20 \mu \mathrm{g} /$ $\mathrm{ml}$ )

\begin{tabular}{lll}
\hline Sample & Peak area (intra-day) & Peak area (inter-day) \\
\hline 1 & 2956 & 3030 \\
2 & 2980 & 3000 \\
3 & 3004 & 2994 \\
4 & 3020 & 3015 \\
5 & 2990 & 3012 \\
6 & 2998 & 2960 \\
STD DEV & 21.93 & 24.02 \\
\%RSD & 0.733 & 0.800 \\
\hline
\end{tabular}

Table 4 Result of accuracy study (recovery result)

\begin{tabular}{llll}
\hline $\begin{array}{l}\text { Level } \\
(\%)\end{array}$ & $\begin{array}{l}\text { Spiked amount }(\boldsymbol{\mu g} / \\
\mathbf{m l})\end{array}$ & $\begin{array}{l}\text { Found amount }(\boldsymbol{\mu g} / \\
\mathbf{m l})\end{array}$ & $\begin{array}{l}\text { Recovery } \\
(\%)\end{array}$ \\
\hline 80 & 16 & 16.0 & 100.00 \\
100 & 20 & 20.3 & 101.50 \\
120 & 24 & 24.4 & 101.66 \\
\hline
\end{tabular}

Table 5 Result of robustness study

\begin{tabular}{lll}
\hline Parameter & Amount found $(\boldsymbol{\mu g} / \mathbf{m l})$ & Recovery $(\%)$ \\
\hline Flow rate $\mathrm{ml} / \mathrm{min}$ & & \\
0.9 & 19.8 & 99.0 \\
1.0 & 19.8 & 99.0 \\
1.1 & 19.7 & 98.5 \\
\%RSD & & 0.29 \\
Acetonitrile:water & & \\
68:32 & 19.4 & 97.0 \\
$70: 30$ & 19.8 & 99.0 \\
72:28 & 19.7 & 98.5 \\
\%RSD & & 1.06 \\
\hline
\end{tabular}


Table 6 Result of solution stability

\begin{tabular}{ll}
\hline Time (h) & Area \\
\hline 0 & 3022 \\
8 & 3016 \\
16 & 3009 \\
24 & 2998 \\
\hline
\end{tabular}

Table 7 Analysis of clotrimazole gelatin

\begin{tabular}{lll}
\hline Claimed amount $(\boldsymbol{\mu g} / \mathrm{ml})$ & Found amount $(\boldsymbol{\mu g} / \mathbf{m l})$ & Recovery $(\%)$ \\
\hline 20 & 19.6 & 98 \\
\hline
\end{tabular}

\section{Conclusion}

The developed HPLC method is simple, accurate, and precise. The results of the statistical analysis demonstrate that the values of the validation parameters are acceptable, and therefore, the method is suitable for the quantitative determination of clotrimazole in gelatin film formulation. Additionally, the method does not involve any pre-procedure such as extraction. Similar methods could be developed for the estimation of active ingredients in the gelatin film formulations. Validated HPLC methods are required in the drug development process and pharmaceutical industry.

\section{Abbreviations}

HPLC: High-performance liquid chromatography; ICH: International Council for Harmonization; RSD: Relative standard deviation

\section{Acknowledgements}

The authors are thankful to Principal, DSTS Mandal's College of Pharmacy, Solapur for the support.

\section{Authors' contributions}

KP designed the study and supervised it. SM performed the experiments and was a major contributor in writing the manuscript. Both authors have read and approved the final manuscript.

\section{Funding}

No funding was received.

\section{Availability of data and materials}

Available on request.

\section{Declarations}

Ethics approval and consent to participate

Not applicable.

\section{Consent for publication}

Not applicable.

\section{Competing interests}

The authors declare that they have no competing interests.

\section{Author details}

${ }^{1}$ DSTS Mandal's College of Pharmacy, Solapur, India. ${ }^{2}$ Institute of

Pharmaceutical Sciences, Gulbarga, India.
Received: 25 March 2021 Accepted: 22 June 2021

Published online: 30 June 2021

\section{References}

1. PubChem Compound Summary for CID 2812, Clotrimazole. https://pubchem. ncbi.nlm.nih.gov/compound/Clotrimazole. Accessed on 29 Mar 2021

2. Usman S, Zulfiqar A, Shah J, Ramesh V, Sudhir S (2017) Modification and validation of HPLC analytical method for estimation of clotrimazole in health care products. Nat Prod Chemi Res 5(1):1-7

3. Beigi F, Imani M, Payehghadr M, Hosseini H (2011) SPE-HPLC method for determination of ketoconazole and clotrimazole residues in cow's milk. J Braz Chem Soc 22(9):1679-1685. https://doi.org/10.1590/S0103-50532011 000900009

4. Rajameena R, Rama K, Muthulakshmi C (2013) RP-HPLC method development and validation for estimation of clindamycin phosphate and clotrimazole in pharmaceutical dosage forms. Int Res J Pharm 4(7):141-146. https://doi.org/10.7897/2230-8407.04731

5. Dhudashia K, Patel A, Patel C (2013) Development and validation of a reversed-phase HPLC method for simultaneous estimation of clotrimazole and beclomethasone dipropionate in lotion and cream dosage form. Chronicles Young Sci 4(2):102. https://doi.org/10.4103/2229-5186.115548

6. Hájková R, Sklenárová H, Matysová L, Svecová P, Solich P (2007) Development and validation of HPLC method for determination of clotrimazole and its two degradation products in spray formulation. Talanta 73(3):483-489. https://doi.org/10.1016/j.talanta.2007.04.023

7. Abdel-Moety E, Khattab F, Kelani K, AbouAl-Alamein A (2002) Chromatographic determination of clotrimazole, ketoconazole and fluconazole in pharmaceutical formulations. Farmaco 57(11):931-938. https://doi.org/10.1016/S0014-827X(02)01270-3

8. Wang L, Li Y, Jiang B, Zhao W (2014) Determination of the active ingredients in simple-recipe ointments by centrifugal partition chromatography. Anal Methods 6(14):5245-5249. https://doi.org/10.1039/ c4ay00131a

9. Parmar P, Mehta A (2009) Development and validation of hptlc method for the estimation of clotrimazole in bulk drug and tablet formulation. Indian J Pharm Sci 71(4):451-454. https://doi.org/10.4103/0250-474X.57299

10. Abdelmageed $O$, Khashaba $P$ (1996) Spectrophotometric determination of clotrimazole in bulk drug and dosage forms. Talanta 40:1289-1294

11. Bedair M, Korany M, Elsayed M, Fahmy O (1989) Derivative spectrophotometric determination of clotrimazole in single formulations and in combination with other drugs. J Assoc Off Anal Chem 72:432-435

12. Bodiwala K, Shah S, Patel Y, Prajapati P, Marolia B, Kalyankar G (2017) Simultaneous estimation of ofloxacin, clotrimazole, and lignocaine hydrochloride in their combined ear-drop formulation by two spectrophotometric methods. J AOAC Int 100(1):38-44. https://doi.org/10. 5740/jaoacint.16-0229

13. Validation of Analytical Procedures Q2(R1). https://database.ich.org/sites/ default/files/Q2\%28R1\%29\%20Guideline.pdf. Accessed on 29 Mar 2021

\section{Publisher's Note}

Springer Nature remains neutral with regard to jurisdictional claims in published maps and institutional affiliations.

\section{Submit your manuscript to a SpringerOpen ${ }^{\odot}$ journal and benefit from:}

- Convenient online submission

- Rigorous peer review

- Open access: articles freely available online

High visibility within the field

- Retaining the copyright to your article

Submit your next manuscript at $>$ springeropen.com 